\title{
PHONOHOLISM - A NEW BEHAVIORAL ADDICTION
}

\section{B. Hoffmann*}

\author{
Institute of Applied Social Science, University of Warsaw, Warsaw, Poland
}

\begin{abstract}
In many countries of the world there are growing phenomena of uncontrolled staying of a young man in the virtual world. Cyberspace created by new technologies has become a real competitor to the elements of the so called traditional world, replacing landline phone and the post, radio, television, print media and books. In recent years, there have been more and more talks about new addictions that are associated with development of modern civilization as well as changing mores.

In the publication by Timothy Gray and Aaron Kelly arise questions: "When was the last time you left a house without a phone?", "Can you survive a week without a phone, a day, an hour?" "Can you ever make do without a phone?" (1). Probably the vast majority of us would answer negatively. It is worth to add to these questions one more: "Where is the border line between a reasonable use of a phone and phone dependence?"
\end{abstract}

Key words: phonoholism, mobile phone addiction, habit and impulse disorder, nomophobia

\section{Mobile phone as a new means of communication}

The concept of a device resembling a cell phone already appeared in the early 40th of the XXth century (2) in the United States, but for the first cordless phone you had to wait until 1971. "The homeland" of universal today "cell" is Finland - the country in which the world's first commercial line of mobile telephony was launched.

In a short time, mobile operators have arisen in other countries of the world. Of course, the first mobile phones created on a basis of the American prototype, did not resemble today's. They were large, heavy and required frequent recharging. Initially they were used by businessmen, truck drivers and developers. After 1987 the first mobile phones were introduced to sale for individuals. With the expansion of the mobile telephony not only a demand increased but also customers' expectations as to the functionality and appearance of phones. Thus, a mobile phone has stopped to only fulfill its original function.

As the data of the Office of Electronic Communications (3) indicate, in recent years mobile telephony has become the most popular telecommunications service in most countries

*Correspondence to: Beata Hoffmann, Institute of Applied Social Science, University of Warsaw, Warsaw, Poland, hoffmann.beata@gmail.com of the world. One can watch not only the increase in a number of people using a mobile phone in order to call, but also an increasing number of users who prefer mobile access to the network via a phone.

While the aim of a landline phone is primarily to enable conversation, a mobile phone meets many more features. It allows you to send multimedia messages like EMS and MMS, surf the Internet, watch TV programs, take pictures or record videos. Thanks to the "cell" you can play, listen to music, use an alarm clock or flashlight. The phone took over a function of a calendar, notebook or notepad.

Many of its features have contributed to changes in a way people communicate and in their interpersonal relationships. According to Tim Dant, things that we create, receive and use, are symptoms of social forms (4), so no wonder that also a cell phone contributed to transformation of behaviors and customs.

Unlike a landline phone, a mobile phone primarily made public a content of talks, as well as released a coercion of immediate action at many of its users: initiating a conversation or reading and replying to text messages. A mobile phone has gone beyond its utilitarian functions; has become a determinant of a status, social position, and its frequent answering became a testimony of having a big group of friends and wide social contacts. 
Mobile phones are used by people of all ages, but this form of communication enjoys a particular popularity among the young. As the results of the study (5) conducted on a representative sample of Poles at age of 12-19 years old show, spending a day without a "cell" is unimaginable for $36 \%$ of the respondents.

To the question, "What would you do if you forgot to take your phone", "I would definitely go back home" answered $27 \%$ of respondents. A similar number of students - $28 \%$, although did not go back, but would feel anxiety in connection with it. What phone is so necessary for? First of all, students use it to communicate with other people - that is, sending text messages (76\%) and calling (70\%). On further position one can find listening to music - for this purpose $65 \%$ of teenagers use a phone every day or almost every day. Taking pictures and videos with a cell happen among $92 \%$ of respondents. As many as $30 \%$ of people in the specified group of age, take photos and videos several times a week, 17\% - every day or almost every day.

Surfing through the Internet and chatting with a phone with a similar frequency applies to $12 \%$ of examined young people. According to the results, a phone as the indispensable tool for information is treated by nearly two-thirds of teens - $68 \%$. Beyond frequency of usage, the other challenge turns out to be a telephone savoir vivre. According to its principles, there are situations and places where we do not use a mobile phone and in case of any urgent need, we do it in a discreet and unobtrusive way to others. Meanwhile, $60 \%$ of young people use a phone in a classroom, (also during tests and examinations - 18\%). The last bastion of the traditionally understood "familiarness" - dinner consumed by relatives - is no longer a reason for not using a phone for almost half of teenagers - up to $44 \%$.

Cinema and theater in particular, is one of the last places where someone has courage to loudly and explicitly ask for turning off mobile phones. Accustomed to (or already addicted to?) teenagers use mobiles also there - as much as $28 \%$, which is almost a quarter of respondents. During the church service, $8 \%$ of young people used cell phones. What turns out to be so important to use a phone in "forbidden" places? In light of the study, for $68 \%$ of young people a phone is a source of entertainment and a way to maintain social contacts (6).

Also, the time of using a mobile phone has been the subject of research interests.
According to the survey carried out among junior high school students in the Mazowieckie Voivodeship in 2008, which covered about 140 young respondents, the average time of using a mobile phone was over 5 hours. It should be noted, however, that $16 \%$ of respondents used a phone from 5 to 10 hours, and $8 \%$ said they used it even more than 10 hours a day. It also turned out that most high school students (88\%) do not turn off a phone at night and 50\% devote their attention to it during classes, doing particularly such activities as: watching time, forwarding signals or messages, gaming and even holding conversations ( 7).

In turn, James Roberts from the School of Business at Baylor in Texas, basing on studies of American cites, quotes data which show that young people at age of 18 to 29 years old send, an average, 109.5 of text and MMS messages a day, they also receive about 113 messages per day (including promotional and advertising ones), about 60 times/ a day check a condition of their phone (battery level, checking a screen in terms of possible missed calls and messages) (8).

The attitude towards a mobile phone is often different than towards a washing machine, vacuum cleaner or even the aforementioned landline phone. Although a phone is a technical means, the link between a user and a cell phone, certainly goes beyond the interest in a simple device and desire to experience pleasure of using it. The attitude towards a phone is being transformed into something that according to Guerreschi, resembles emotional relationship (9). You can also note a kind of personification of the "cell", which becomes our link with the world and the other person, a guarantee of the sense of security.

\section{Mobile phone - potential threats}

Unfortunately, next to the obvious advantages and conveniences, a mobile phone carries certain dangers. Although mobile phones are the essential part of the culture of consumption, they can, however, contribute to disrupting or even destroying our personal relationships (10).

This applies particularly to those who abuse mobiles that are use them in so-called "a risky way". Risky use of a phone, also called an abuse can affect people of any age, but young people are particularly threatened.

It results in withdrawal from participation in the outside world and deprivation of ability of direct contact. Time spent in solitude increases in proportion to time spent in social groups, generating, in fact, a feeling of loneliness. To 
deal with it, a man increasingly uses a phone, trying to gain a sense of participation in social life. He does not note, however, shallowness and uncertainty of these contacts.

Another worrying phenomenon is a syndrome of being in two places at once. This problem reaches people who cannot completely turn off a phone, and thus, they cannot switch to only take part in classes or other activities. Leaving a switched on phone makes a body show a full readiness to receive additional signals. Such situations occur both, in the workplace and more and more often during the classes. Many students and pupils are involved in text messages correspondence to a much greater extent than in undergoing classes or other activities (11). Many of them are occupied in an equally high degree of checking whether any text message arrived or whether any call is missed.

Involvement, not to say "escape into a phone" hampers development of peer contacts during school breaks, and the image of a group of students bending over their phones, comparing ringtones, wallpapers and other "achievements", or writing text messages in isolation, is almost a regular part of the landscape of a school corridor. Among other risks there are: a relationship based only on exchange of information without an ability to create a more complicated statements or fixation of spelling, stylistic and punctuation mistakes of test messages. The form of communication itself can cause confusion because the context of declamation is often unclear. Also, failure to answer a phone or its turn off may become a cause for concern of friends and create a variety of awkwardness.

It is also worth to mention the adverse effects on health of people using frequently a mobile phone, especially on their nervous system electromagnetic radiation emitted by a phone (12).

At the end, it is worth to mention that the risky use of mobile phone causes a real threat not only for adults, but also young drivers. As it comes from police statistics - a mobile phone call is still one of the main offenses caused by drivers, and even more dangerous than a phone call is writing text messages while driving, which is also not uncommon (13). As you can see, the use of mobile phone brings many changes in behavior and the situation in which an entity is unable even for a short time to give up a use of a phone, should prompt to think whether the first signs of addiction appeared.

\section{Mobile phone addiction}

We used to assume that the term dependence refers to the situation in which there is a living organism and his interaction with an addictive substance. The problem of addiction, however, concerns a much larger area of human behavior. The addiction can be the acquired, persistent need to perform/ repeat certain actions. Addictions, characterized by just such a feature are called behavioral addictions, nonsubstance, dysfunction of habits and instincts, or simply activity addictions. In recent years, one can observe not only an increasing number of people addicted to behaviors, but also an increasing amount of addictions themselves. They seem to be particularly important because the majority of behavioral addictions are accompanied by the low public awareness, environmental laxity or even approval for some compulsive behaviors.

Mobile phone addiction, called phonoholism is a new phenomenon, but the mechanisms of addiction themselves do not differ significantly from the other forms of dependence. The first country, in which one can observe this kind of addiction, was China, and there also appeared its English name: mobile phone dependence syndrome.

Phonoholism belongs to the so-called nonsubstance addiction, or sometimes is called "disorder of habits and instincts." A characteristic feature of this kind of addiction is repeated actions without a clear rational motivation, which usually harm a patient and sometimes the others. A patient determines such behaviors as related to the impulse to act, which cannot be controlled. Thus, they are considered in terms of impaired control of impulsive behaviors (14). Regardless of the fact that different behaviors are sometimes called addictions or addictions can take various forms, one can distinguish a series of identical symptoms which fall within the area of disturbed mental, physical and social functions.

In addition to other kinds of addiction, such as addiction to work, eating, surfing the Internet, shopping, gambling or sex, phonoholism is a new, complex issue, especially since younger and younger people become its "victims".

The term "phonoholism" include several types of addiction:

- dependence on continuous (long/ frequent) calls; addicts feel the constant compulsion to calling, and a phone conversation discharges their inner tension only for a short time. Usually they find many reasons to contact the others, thanks to which they justify their behavior. 
- addiction to text messages; addicts feel the continuous compulsion to send and receive text messages. Number of sent and received text messages is a prerequisite for their well-being and mood. Number of outgoing text messages reaches several hundred per day.

- dependence on new models of phones; addicts feel the increasing compulsion to frequent changes of models of telephones, they spend an extremely large amount of time on tracking changes in the mobile market.

Moreover, among the types of phonoholism there are also mentioned:

- addiction to gambling; addicted person identifies telephone with a games console

- dependence on using the Internet via a phone

In the case of dependence on mobile phone at symptomatic level, we encounter similar characteristics of the clinical picture as in substance addictions. Among the symptoms of the syndrome of dependence on a mobile phone the following elements are most often mentioned: feeling of coercion to constant contact with another person, attaching a great importance to having a mobile phone and to its quality, feeling a deep discomfort in the case of battery discharge, constant listening for a call signal or sound of coming text message.

The obvious here is the continuous desire to perform a specific task, loss of control affecting the extension of time and frequency of its performance, the appearance of a withdrawal syndrome in a form of various ailments in the case of necessary cease of further activity and compulsive desire to continue the activity despite its obvious negative impact on mental, social and even physical functioning of a human being (15).

Addicts are also often characterized by SWT syndrome, i.e. the syndrome of switched off phone. It means a panic-stricken fear because of the switched off phone, even for a very short time, and in the absence of access to an active phone, appearance of withdrawal syndrome similar to that found in other addictions.

In the article titled Break free from Nomophobia, drunkorexia, Archan Jayakumar draws attention to the problem of monophobia (16) that is a state of a strong psychological discomfort, and often also physical discomfort caused by lack of access to the active cell phone (17). This condition arises particularly in the case of a phone's battery discharge, lack of its range or accidental leaving at home.

Trakia Journal of Sciences, Vol. 15, № 4, 2017
Among other symptoms of addiction there are mentioned: frequent wakening during a night equally to read received text messages as well as checking if any text messages arrived, nervous tics usually involving constant inserting and removing hands from pockets, looking at watch, searching for a phone when a bell is heard somewhere around (18). It is also worth to mention about the so-called "thumb syndrome" - a disease of the ischemic thumb, caused by continuous "text messaging", which is a particularly characteristic complaint of people addicted to a mobile phone.

\section{CONCLUSION}

Increasingly there are questions what may be the causes of excessive use of a phone? Among the arguments justifying the frequent use of "cells" there are quoted considerations of safety and comfort. The real reasons however, happen to be different: from social phobia and fear of loneliness up to an attempt to meet needs of affiliation, belongingness to a peer group. In many cases, the device becomes a "cure" for stress, loneliness or inability to positively cope with frustration.

A shy teenager, relating to family ties with a distance, who has difficulties to boast about a large group of frequently visited him friends, may have difficulty in establishing contacts and demonstrating affection. It is much easier for him to maintain relationships using electronic tools, than to do it directly. Good and expensive phone has become a symbol of social status, something that one can be proud of, as of a watch or bike in the past. Bringing a fashionable phone model to the school leads to mood improvement, makes that someone feels important, can impress his peers (19).

Preventive measures can help to reduce a scale of phonoholism. It seems particularly important to develop different skills of coping in so-called difficult situations. A significant role is played by information and education strategies that can help to develop skills to cope with stress and improve interpersonal relationships. A huge role relates to alternative strategies which aim to help in addressing important psychological needs, including emotional ones, of course. It is necessary to sensitize on the problem not only the closest environment of an individual but also teachers, educators and school psychologists and doctors as well.

However no less important is to focus on the so-called risky use of a phone. When it takes place, it is fully justified to introduce some measures restricting the use of the device. To 
that end, it is worth to create a zone free from a phone, both at home and outside, resign from a constant availability of "cells", choose such time during a day, when a phone is turned off, be subject to coercion of immediate answering to text messages.

Many people find it difficult to accept the fact that one can become addicted to something that is not only a substance introduced into the body but actually constitutes a natural part of life. This is becoming a very dangerous feature of this addiction, which certainly deserves attention.

\section{REFERENCES}

1. Gray T., Kelly A., Cell Phone Addiction and Texting Addiction. Kindle Edition, 2012.

2. See: Farley T., Mobile telephone history, Telektronikk 3/4, p. 22 - 34, 2005.

3. Following data from the Office of Electronic Communication: www.uke.gov.pl, access: 15.02.2017

4. Dant T., (transl. Janusz Barański), Kultura materialna w rzeczywistości społecznej. Wartości, działania, style życia [Material Culture in the Social Word. Values, Activities, Lifestyles], Wydawnictwo Uniwersytetu Jagiellońskiego, p. 23-24, 2007.

5. Polish nationwide research "Youth and mobile phones," carried out in March 2011 by TNS OBOP on a representative group of 400 Poles aged 12-19 years old. The research was conducted at the request of Internetq Poland $\mathrm{Sp} \mathrm{z}$ o.o., the initiator of the educational campaign: Attention! Phonoholism.

6. On the basis:

http://www.uzaleznieniabehawioralne.pl/ra porty-z-badan/fonoholizm-skala-zjawiskawsrod-polskich-nastolatkow/, access: 8.02.2017

7. M. Jędrzejko, A. Taper, Mechanizmy uzależnień w wielkiej sieci [Mechanisms of addiction in a large network] Wyd. Pedagogium, Warszawa, p. 80, 2010.
8. Alleyne R., Mobile phone addiction ruining relationships, "The Telegraph", 30 November 2012.

9. Guerreschi C., (transl. Anna WieczorekNiebielska), Nowe uzależnienia [New addictions. Le nuove dipendenze], Salwator, Kraków, p. 206, 2010.

10.Alleyne R., op. cit.

11.Sorokosz I., Odrzucić, odebrać, odpisać..., czyli magia telefonu komórkowego - cz. I, w: Mieczysław Plopa (red.), Człowiek u progu trzeciego tysiąclecia. Zagrożenia i wyzwania, t. 2 [Reject, Pick up, Write back ..., that is a magic of a mobile phone - part. I], in: Mieczyslaw Plopa (ed.), A man on a threshold of the third millennium. Threats and challenges, Vol. 2, Wyd. Elbląskiej Uczelni Humanistyczno- Ekonomicznej, Elbląg, s. 473-477, 2007.

12.More: : Woronowicz B. T., Uzależnienia. Geneza,terapia, powrót do zdrowia [The addictions. Origins, therapy, recovery]. Media Rodzina and Parpamedia, Warszawa, 2009

13.http://prawo.gazetaprawna.pl/artykuly/4154 45, access: 20.12.2016

14. Woronowicz B. T., op. cit., s. 461

15. Cierpiałkowska L., Kierunki rozwoju współczesnej psychologii uzależnień, [New directions in the psychology of addiction]. In: Cierpiałkowska L. (ed.), Oblicza wspótczesnych uzależnień [The many faces of contemporary addictions].

Wydawnictwo Naukowe UAM, Poznań, p. 21, 2006.

16.The term "nomophobia" for the first time appeared in the UK in 2008 and is used sometimes also for the other mobile technologies, as even the mobile Internet.

17.Jayakumar A., "Break free from Nomophobia, drunkorexia", www. Midday.com., April 3, 2008, Retrieved 201108-10.

18.Guerreschi C., op. cit., p. 208

19.http://www.uzaleznieniabehawioralne.pl/ra porty-z-badan/fonoholizm-skala-zjawiskawsrod-polskich-nastolatkow/ 